inacessiveis para brasileiros (como Gregório Bezerra, em 24 de outubro de 1967, quando êsse personagem se encontrava prêso, em Recife); ou documentos também inacessíveis (como o relatório do inquérito instaurado contra Luiz Carlos Prestes e outros por ocasião da revolução de março de 1964, preparado pelo Departamento de Ordem Política e Social da Secretaria de Segurança Pública do Estado de São Paulo).

Dessa forma, estudiosos como Dulles podem dar uma contribuição original (ainda que defeituosa) ao conhecimento da história do Brasil para os próprios brasileiros.

MANOEL TOSTA BERLINCK

\title{
Movimentos Partidários no Brasil
}

Por Paulo Roberto Motta. Rio de Janeiro, Fundação Getúlio Vargas, 1971.

Ainda que haja numerosos estudos setoriais sôbre a dinâmica dos partidos políticos brasileiros, não havia até a publicação dêste livro, um tanto didático, nenhum que resumisse, de maneira sistemática, o que já se conhece sôbre 0 assunto.

Nesse sentido, o livro de Paulo Roberto Motta vem suprir uma lacuna na literatura política do Brasil.

O escopo do livro não é, entretanto, apenas o de sistematizar conhecimentos esparsos.

Nas palavras do próprio autor, o livro "visa, especìficamente, a levantar hipóteses sôbre as estratégias da elite agrária e dos militares como fatôres de mudança no sistema partidário" (p. XIV).

Para tanto, o autor adota uma postura teórica, comum na moderna ciência política, segundo a qual "o processo político é, em última análise, um processo grupal, que enfatiza os interêsses manifestados por diversos grupos na formulação de determinadas políticas. Os grupos são vistos principalmente no seu aspecto estrutural e nos motivos que condicionam a sua existência, ou que os levaram a defender certos interêsses" (p. VI).

De acôrdo com essa definição, o autor concebe a estratégia dos militares como "qualquer intervenção dêsse grupo institucional - os militares - na vida política, de modo a ocasionar a formação, extinção ou divisão de qualquer partído político" e a estratégia da elite agrária "como sendo qualquer forma de comportamento dêsse grupo não-associativo - a elite agrária - na vida política, de modo a ocasionar a formação, extinção ou divisão de qualquer partido político" (página XIV).

A partir dessa postura teórica, Paulo Roberto Motta analisa as transformações ocorridas no sistema partidário brasileiro, no período compreendido entre a independência (1822) e a extinção dos partidos políticos (1965).

O autor, para realizar tal análise, parte das seguintes premissas: " $1 .^{a}$. os partidos politicos brasileiros carecem de base ideológica e geralmente cresceram em tôrno da personalidade de um líder; $2 .^{\mathrm{a}}$. os partidos políticos brasileiros não são nacionalmente integrados e, sim, fundados em bases regionais. Alguns dêles atingiram dimensões nacionais através da aliança de líderes regionais; $3^{a}$. os partidos políticos brasileiros são controlados por grupos oligárquicos. A oligarquia dos partidos é constituída de líderes regionais com prestígio nacional, os quais não sòmente promovem alianças entre si, mas também tentam traduzir os seus desejos nas normas e programas partidários; e $4 .^{\mathrm{a}}$. os partidos políticos brasileiros têm mostrado, desde 1945, uma tendência para adquirir características de partidos de classe" (p. XIII).

Em seguida, o autor passa a analisar os partidos políticos imperiais para depois exa- 
minar os partidos políticos republicanos e termina com o exame do bipartidarismo. Em cada um dêsses períodos, o autor analisa separadamente os fatos, a estratégia da elite agrária e a estratégia militar nos movimentos partidários.

Segundo Paulo Roberto Motta, o tipo de contrôle exercido pela elite agrária no sistema partidário imperial pode ser definido como globalístico, pois todo o sistema era diretamente dependente dela. "Durante quase todo o período do Império, a ausência de grupos opositores deu aos proprietários rurais o contrôle absoluto do sistema polítíco. Na medida em que uma elite militar e a classe média se iam formando, a classe agrária concentrava seus esforços no domínio dos altos escalōes do govêrno e dos partidos políticos. Dessa forma, a política partidária se passava dentro dos mesmos clãs rurais e as disputas havidas não eram mais que uma divisão intra-elite. As lutas pelas lideranças partidárias significam, de certa forma, uma simulação democrática já que podiam, a princípio, significar uma visão dentro do sistema, como um todo". E, mais adiante, conclui que "os partidos, por conseguinte, eram uma contingência dêste domínio e foram criados pelos senhores de terra para facilitar o contrôle do povo e, também, para simular um govêrno democrático, diminuindo, assim, a pressão para participação no sistema partidário" (p. 11).

A estratégia militar, nesse mesmo período, significou uma sanção negativa ao sistema partidário do Império. "Foi uma resposta dos militares ao tratamento recebido pela elite dirigente da monarquia, para a qual os partidos politicos eram um instrumento proveltoso. A intervenção militar era dual; primàriamente, uma intervenção direta, de modo a defender seu próprio orgulho e prestígio sacudido pela monarquia; em segundo, era uma intervenção da classe média, em que os militares constituíam o instrumento utilizado para tomar o poder. A influência da classe média pode ser notada com a decisão imediata do primeiro govêrno republicano de abolir o poder moderador, a vitaliciedade dos senadores, e o direito de representação baseado em renda particular, fatôres que constituíam obstáculos à sua participação na política" (p. 17).

A estratégia da elite agrária em relação aos movimentos partidários durante a República pode, segundo Motta, ser definida como teleológica, "uma vez que limitava a manutenção dos valôres da elite agrária no processo decisório político".

Embora houvesse implantado, formalisticamente, sistema multipartidário competitivo, uma série de mecanismos de contrôle, desenvolvidos por tal elite, não permitia o acesso real de outros grupos ao poder político. Todos os partidos tinham igualdade de participação formal, mas, na prática, a estratégia da elite agrária era a neutralização.

Os mecanismos básicos para a execução desta estratégia foram, como vimos, a continuação, ainda que em menor escala, das $m a ́-$ quinas de contrôle eleitoral, que favoreciam as eleições no interior, pela sobrevivência, em certas regiões, dos sistemas de clãs eleitorais; o contrôle do PSD - partido de função hegemônica e que, através de alianças nacionais e regionais com partidos menores, neutralizava a ação dêstes e, ainda, o contrôte da burocracia, que evitava os valôres da nãoelite no processo de formulação de políticas.

As dificuldades em conciliar o sistema formal de competição partidária e os mecanismos de participação política fizeram surgir organizações extrapartidárias, que concorreram não só para o enfraquecimento dos partidos, mas também para desintegrar o próprio mecanismo de contrôle que dependia de um partido forte" (p. 50).

A partir dêsse ponto, o livro de Motta fica confuso. A sua análise sôbre a estratégia militar durante a República e, depois, tôda a sua análise a partir de 1964 é bastante insatisfatória. 
Tais fraquezas não são, entretanto, devidas exclusivamente ao autor, mas ao estado geral de conhecimento sôbre a matéria.

O livro de Paulo Motta é, no entanto, honesto e, por isso, sugere lacunas no conhecimento político do Brasil que podem ser investigadas futuramente.
Em resumo, Movimentos partidários no Brasil pode ser utilizado como livro-texto em cursos de política brasileira e como guia para aquêles que desejam pesquisar sôbre o assunto.

\section{Ensaios de Sociologia do Desenvolvimento}

Por Luiz Pereira. São Paulo, Livraria Pioneira Editôra, 1970. 158 p.

O autor nos adverte em sua nota prévia que os quatro textos do livro têm a intenção de "servir como obra didática, tanto pela informação como pela provocação de reflexões críticas em face das interpretações nêles formuladas". Vejamos os textos:

1. "História e planificação". Trata-se de uma contribuição ao que seria sociologia do planejamento. Assim, o autor procura caracterizar o planejamento como processo social, estabelecer as conexões entre política e planejamento e identificar as diferentes formas de planejamento. Isto êle faz através da utilização de categorias-chave da sociologia estrutural e da sociologia sistemática. Mostra que como categoria histórica, o planejamento só pode ser percebido no quadro da sociologia estrutural e que no âmbito da sociologia sistemática pode-se chegar a tipologias. Chega, assim, a uma tipologia do planejamento a partir de um tipo mais amplo: o contrôle social. Tenta, em seguida, inserir a tipologia dentro das preocupações teóricas da sociologia estrutural e, aí, poderíamos perguntar se a didática não se faz em detrimento do método. Mas é através dela que o autor nos mostra, muito bem, que uma determinada concepção sôbre planejamento implica numa determinada visão de política e de Estado, bem como da história e esta, por sua vez, numa concepção da teoria do conhecimento. Distinguem-se, didàticamente, três correntes principais: realismo, idealismo e materialismo dialético. $O$ autor apresenta, então, as posições de cada uma dessas correntes nos quatro diferentes níveis acima mencionados; e, finalmente, a identificação das diferentes formas de planejamento, nas diferentes fases do desenvolvimento capitalista.

2. "Caracterização do subdesenvolvimento". Nesse ensaio, o subdesenvolvimento é considerado como categoria histórica. O autor apresenta três conjuntos de caracterizações econômicas do subdesenvolvimento: a tendência estruturalista representada por Celso Furtado, Raymond Barre e Elias Gannagé; a tendência dinâmica representada por Ragnar Nurkse e Gunnar Myrdal; finalmente, a tendência marxista representada por Charles Bettelheim e Gunder Frank. Através de comparações e uma análise crítica, mostra as insuficiências analíticas de certas tendências. Aqui, a didática enriquece o processo analítico do autor e o subdesenvolvimento aparece como "produto da dinâmica interna da realização do tipo macroestrutural capitalista" (p. 95).

3. "Urbanização sociopática e tensões sociais na América Latina". Nesse ensaio, o autor procura mostrar que a instabilidade política é inerente às formações subdesenvolvidas. A concepção de instabilidade política do autor é insatisfatória (cf. por exemplo, 